\title{
DRINKING IN IRON AGE ATCHANA
}

\author{
Marina PUCCI
}

\begin{abstract}
Although archaeological results at Alalakh/Tell Atchana supported until very recently the view that the site was inhabited until the end of the Bronze Age, recent excavations (2012-2014) carried out in two areas provided data to stress an Iron Age occupation of the site. The study and analysis of the local pottery produced on-site and found in these Iron Age contexts provides very important data on the occupation of the site during this period, pointing out changes and continuity in the morphology of local pottery and, most importantly, emphasising behaviours concerning preparation of food, its consumption and the social activities related to it. Through this study, it is possible to provide hypotheses concerning which social group was still occupying the site in a period of major political changes and external influences. This paper will present for the first time the ongoing study of this material and compare it with the local pottery production of the Late Bronze Age.
\end{abstract}

\section{INTRODUCTION}

The discovery of an Iron Age archaeologically well-stratified accumulation is one of the most recent $(2007,2011-2013)^{1}$ and important discoveries made by the archaeological team directed by Prof. K. A. Yener at the site of Alalakh (Turkey, Hatay). ${ }^{2}$ This discovery opened a completely new branch of research on the transition from the Late Bronze Age to the Iron Age in the settlement system of Tell Tayinat and Tell Atchana. ${ }^{3}$

The study and analysis of the Iron Age architecture, materials and stratigraphy from the site is still in progress, and these will appear in a comprehensive publication, including all aspects of the Iron Age occupation at Tell Atchana. This chapter focuses on a specific feature of the Iron Age I pottery inventory from the site, that is, the vessels related to drinking activities, and it aims to confront the drinking sets at Tell Atchana diachronically and synchronically. After a general presentation of the archaeological contexts and of the main morphological features of the drinking sets, I will compare the Iron Age drinking set with the typical Late Bronze Age drinking sets from neighbouring sites. In particular, I will emphasise those from Alalakh, which have been studied and published by Mara Horowitz, ${ }^{4}$ in order to point out continuity and change in habits from the Late Bronze to the Iron Age.

1 Yener 2013, pp. 20-21.

${ }^{2}$ My warmest thanks go to Prof. A. K. Yener, who asked me to work on the Iron Age pottery from the site and started a fruitful and growing collaboration.

3 The alternation of the leading role of the settlement at the two sites (Mazzoni 1997) seems to be confirmed, however, some overlap in the occupation occurred.

${ }^{4}$ I thank Mara Horowitz, who provided me with draft copies of her articles in print and many details on the documentation system of the pottery at Atchana. 
I will then compare the Alalakh Iron Age drinking set with neighbouring sites from the same period in order to identify the boundary of a ceramic region.

Drinking, as well as eating and cooking, is considered an important cultural aspect of social life during both daily activities and feasting performances; habits related to food and liquid consumption have been largely employed to investigate the cultural identity of social groups and continuity and change in feasting traditions. ${ }^{5}$ Since the first studies concerning drinking habits ${ }^{6}$ and their relevance in understanding social behaviours, archaeologists have been dealing with this topic in the analysis of both specific feasting activities ${ }^{7}$ and the consumption of specific drinks. ${ }^{8}$ Obviously, recovering mannered behaviours presents the usual challenges of constructing methods for correlating temporal and spatial distribution of artefacts with past human action. ${ }^{9}$ Although a primary context would be the best archaeological data to reconstruct functionally related sets, these are extremely rare in the archaeological evidence. Therefore, an approach is employed based on morphological features and the large quantity of material processed, rather than on the "quality" of the deposits. This process implies: first, a selection of the containers which, according to their morphology, were likely to have been used in drinking performances; second, an analysis of the gestures involved in these performances; and third, a comparison with different or similar drinking sets.

The criteria employed to identify drinking containers follows the well-known studies of vessel functions and use; ${ }^{10}$ they are directly related to the morphology of the vessels and their supposed use. A general open shape, which is apt to contain liquids (when not too shallow), is a necessary requirement both for single and communal drinking activity. A content of up to $500 \mathrm{ml}$ of liquids (single sized), an outward-curving or tapered rim to facilitate direct drinking, and a morphology which could be held in the hand are necessary features for single serving and direct drinking. These containers can be filled either from jugs or from larger containers such as kraters or pithoi through the direct immersion of the cup/bowl or the use of specific tools, such as dippers. Communal drinking - that is, directly from a large vessel - requires not only an open and large container, but also the presence of additional tools such as straws (usually with filters when the liquid is the product of a fermentation process). Moreover, texts and iconography dealing with the act of drinking provide further information about this specific performance, both in the Late Bronze and in the Iron Age in the Mediterranean and in the Levant. ${ }^{11}$

\footnotetext{
5 Rabinowitz 2009; Karageorghis 2007.

${ }^{6}$ For the anthropological basis, see Dietler and Hayden 2001.

7 Rabinowitz 2009; Bray 2003; South 2008; Steel 2004.

8 Milano 1994; Stol 1994; Zettler and Miller 1996.

9 Wright 2004b, p. 91.

10 Skibo 2013; Sinopoli 1991, pp. 83-98, 122-124; Mazow 2005, pp. 127-162; Smith 1988.

11 Studies on drinking habits in the Late Bronze Age Mediterranean region were performed by YasurLandau 2010; Steel 2004; Wright 2004a; Hitchcock et al. 2008.
} 
The archaeological eVIdence from Tell Atchana/AlakaH: the archaeOlogical CONTEXTS OF THE IRON AGE LEVELS

Iron Age stratified materials and contexts were discovered in two sectors on the acropolis, ${ }^{12}$ both located in Area 1, one just above the so-called Northern Fortress (Squares 32.52, 32.53 and 32.63) and the second to the west of the temple (Square 42.10). From the point of view of the pottery analysis, however, it is important to clearly distinguish the archaeological contexts of the assemblages found in the area above the Northern Fortress from the ones identified in Square 42.10 near the temple.

In the context above the fortress (Squares 32.53 and 32.63), the largest number of pottery sherds was found reemployed as building material in the paving of an Iron Age structure: this assemblage also included, besides large quantities of Iron Age material, a lower quantity of sherds from the Early, Middle and Late Bronze Ages. This archaeological context was identified for the first time during the excavation campaigns of 2003-2004 in Square 32.53 and interpreted as the remains of Woolley's pottery yard. The concentration of pottery sherds, their mixture and the presence of "pieces of mortars similar to the ones employed in the dig house" led archaeologists to think that the process of accumulation in this area took place during the English excavations at the site, on top of the Level II "original" accumulation. However, in the publication of this material, Yener and Yazıcioglu suggested that several findings from the 2008 excavation could suggest the presence of Woolley's Level O or I in these squares. ${ }^{13}$ Once the neighbouring Square 32.42 was excavated in 2012, it became clear that the straight limits of the sherd layers exposed in 2003 were defined by mud brick walls; thus, they could not be interpreted as the sherd court of Woolley's dig house, but rather as a specific floor feature belonging to a period stratigraphically located above the Northern Fortress. Large pottery sherds were broken directly on the floor and in some cases were laid in several overlapping layers without mortar. The sherds had been removed from their original context, sorted out from the deposit and reemployed as building material. Moreover, the immediate analysis of the assemblages showed that they did not include any sherd or object more recent than the Iron Age II-III; thus, the structure was in use during the Iron Age occupation at the site. ${ }^{14}$ Underneath this building, archaeologists identified the mudbrick structure of the foundation platform of the Northern Fortress, dated to the Late Bronze Age II period. ${ }^{15}$ Therefore, this area resents a phase of abandonment after the construction of the Northern Fortress and a single phase of Iron Age II-III reoccupation with a single building. The pottery found in this floor belongs to a tertiary context.

\footnotetext{
12 See Montesanto this volume; Yener 2013. Iron Age assemblages have also been collected in topsoil accumulations from other squares.

13 Yener and Yazicioğlu 2010, p. 12.

${ }^{14}$ A structure with similar architectural features was excavated at Tell 'Acharneh and was also dated to the Iron Age II (see Fortin et al. 2014, p. 210).

${ }^{15}$ For a discussion on the cultural background, architectural features and chronology of the structure, see Woolley 1955, pp. 166-170, and more recently Akar 2013.
} 
Square 42.10 is located approximately $15 \mathrm{~m}$ southeast of the temple area, without a direct archaeological connection to it. In the temple area, besides the sequence identified by Woolley, a section cleaning in 2001 led archaeologists to identify, only on the top deposits of the baulk, accumulation and architecture which could be related to Woolley's Levels III and II. ${ }^{16}$ The Iron Age phases identified in Square 42.10 will be published in detail separately, ${ }^{17}$ however, for the aims of this contribution, it is important to briefly sketch the sequence inside the trench, in order to better ascribe the pottery collections and illustrate their contexts. In Square $42.10,{ }^{18}$ the excavations revealed a sequence of three architectural local phases dated to the Iron Age (Period 0 in the new general sequence) above a fourth, Late Bronze Age one. The fourth phase, which was brought to light in 2014, is the most recent one in this area to have closed, built spaces and room inventories. In one of the inventories from Local Phase 4, archaeologists found the sealing of prince Tudhaliya, which provided the end of the 14th century as terminus post quem for the deposit in which it was found and the related pottery assemblage. ${ }^{19}$

During the most ancient Iron Age occupation of this area (Local Phase 3a and b), the Late Bronze Age structure of Local Phase 4 no longer existed, and a new floor was constructed above the levelled remains. The area was open during all three sub-phases of the Iron Age, and traces of human activity in the form of installations appear in all three phases, suggesting either glass and metal production (such as the pyrotechnical installation in Local Phase $3 b)^{20}$ or food preparation and consumption (several large plates and cooking pots were found smashed above the tamped earth floor of Local Phase 3a; a few patches of stone installations on a tamped earth surface of Local Phases 2 and 1). The ceramic assemblages from this square are stratified, and those selected for the analysis of this topic belong only to Local Phases $3 \mathrm{a}$ and $3 \mathrm{~b}$; that is, to the most ancient Iron Age occupation at the site. The ceramic material at our disposal consists of approximately 1200 diagnostic sherds from four main contexts (CX 204 and 203, Local Phase 3b; CX 162 and 163, Local Phase 3a).

\section{Drinking SETS IN IRON Age I Tell Atchana/AlalakH}

Both Local Phases $3 \mathrm{a}$ and $3 \mathrm{~b}$ included very rich assemblages, consisting mainly of vessels related to food consumption and food preparation, with a minor quantity related to storage activity. The shapes, which may belong to a drinking set, can be reduced to a handful:

\footnotetext{
16 Woolley 1955, p. 380. This sequence has been reconsidered by several scholars (Na'aman 1980; Fink 2010; Yener 2005). For the 2001 investigations in the trench, see Batiuk and Horowitz 2010, pp. 164-165.

${ }_{17}$ A short overview is provided in Yener and Akar 2013.

${ }^{18}$ I thank here Dr Murat Akar, who provided the necessary information concerning the stratigraphy.

${ }_{19}$ Yener et al. 2014 suggested a date at the end of the 14th century BC, considering that prince Tuthaliya was contemporary to Mursili II.

${ }^{20}$ See Johnson this volume.
} 


\section{Direct drinking:}

I. Small, miniature bowl (BWL_Min; ${ }^{21}$ Fig. 1): this small vessel with outward curving rim, s-shaped (Fig. 1d), conical (Fig. 1a-b) or hemispherical (Fig. 1c) body and thick flat base recurs apparently in small numbers only in the oldest Iron Age occupation (Local Phase $3 b)$. The vessel holds a very small amount of liquid $(0.151) .{ }^{22}$ The clay in all examples is local; the base is simply cut off.

These containers, and the s-shaped variant (Fig. 1d) in particular, are present only in the final stages of the Late Bronze Age occupation at Alalakh (marked in previous publications as HEBL-TR). ${ }^{23}$ Similar vessels were found in the coastal Levant up to Tyre in the 13th century, ${ }^{24}$ and their specific use has not been fully investigated: their small dimensions suggest their use either as tools to collect liquids to be poured into bowls or for the consumption of specialty drinks. The hemispherical version of this miniature shape appears to be completely new in the Iron Age horizon and represents only a smaller version of the well-known hemispherical bowl. Its use seems to be limited to the very early phase of the Iron Age and it can be interpreted as having continuity from the Late Bronze II.

II. Shallow bowl with tapered rim (BWL_Hem; Fig. 2f-g and i): this shape together with BWL_Str (below) is the most common in all assemblages, and they are likely variations of the same form. BWL_Hem consists of a shallow hemispherical body with a slightly outward curving and tapered rim. The base is probably rounded; the size of the diameter ranges from 15 to $20 \mathrm{~cm}$ and the bowl can hold approximately 0.351 of liquid.

III. The Shallow Bowl with straight rim (BWL_Str; Fig 2e and j): a shallow body shape with carination and straight rim characterises this shape. It differs from BWL_Hem only in the very straight shape of the upper part. The dimensions of these vessels are only slightly smaller than BWL_HEM, due to the absence of the outward-curving rim. Their capacity also ranges from 0.3 to 0.41 .

Both shapes recur also in larger dimensions (Fig. $2 \mathrm{k}$ and $\mathbf{1}$ ), which were probably employed for eating.

IV. Hemispherical small bowls (HEBL_FL and CABL; Fig 2a-d and h): several imitations of shallow angular bowls or bell-shaped bowls (Furumark Shape FS 284 and FS 284) appear in the assemblage. The body is hemispherical with a short, outward curving and thickened rim, and a small horizontal handle (elliptical in section) is attached to the body underneath the rim. One bowl (Fig. 2b) shows a body and rim shape which is very similar to the other examples; however, it is not possible to state whether the

${ }^{21}$ Shape codes employed in this chapter are mainly those created by Mara Horowitz for the Late Bronze Age sequence, with several additions created for the Iron Age inventory.

${ }^{22}$ Volumes are calculated using the program Pot-Utility, kindly provided by the ARCANE project (Thalmann and Arcane project 2006).

${ }^{23}$ Horowitz, in press, fig. 8: 2-4. The shape apparently has no local precedent, and it is interpreted as ultimately belonging to a North Central Anatolian repertory,

24 At Arqa, Lev. 11, at Ugarit (Courtois 1969, fig. 6c), at Byblos (Salles 1980, pl. 20), at Tyre (Bikai 1978, pl. XLVIIa:15-17), and at Tell Kazel (Badre et al. 1994, fig. 42c). I thank Dr H. Charaf for the information she provided me concerning this specific shape. 
absence of the handle is due to the state of preservation or to the fact that it is a different shape, without handles. Besides the presence of the horizontal handle, the shape and size of these vessels is identical to the other drinking vessels; they contain approximately $0.35-0.41$.

All these shapes are intended to be single-sized drinking vessels. From a morphological point of view, the shape of the body tends to be shallow and hemispherical, it can be held in one hand, the shape of the rim facilitates the consumption of the liquid, and the vessel could contain either a very small or limited quantity (up to $0.4 \mathrm{l}$ ). All shapes except for those described in group IV above were also part of the Late Bronze Age assemblage, although with minor differences: BWL_Hem and BWL_Str are also in the Atchana Late Bronze Age II assemblage, but more rounded, and the rim is rarely outward curving. In particular, the Iron Age version of this type seems to be related to a shape which is characterised by thin walls and tapered rim, as well as a straight upper body, and which appears only in the final stages of the Late Bronze Age occupation at the site. ${ }^{25}$ Hemispherical bowls, as well as those with straight vertical rims, ${ }^{26}$ are well known in the Late Bronze Age of northern Syria. ${ }^{27}$ This morphology seems to continue into the Iron Age, when it becomes squatter and the rim tends to become more outward curving. The simple hemispherical shape of the bowl is frequently represented in drinking scenes from the Late Bronze and beginning of the Iron Age. ${ }^{28}$

Painted decoration is not very common. In the assemblage presented here, it occurs only in one drinking vessel, which belongs to group IV and has been published by Koehl. ${ }^{29}$ Furthermore, although the shape and decorative patterns imitate Late Helladic IIIC production, it is of a local ware and probably belongs to the same local production responsible for the group IV shapes. Red slip decoration is never employed in drinking vessels, but only in serving plates from these early Iron Age assemblages. This surface treatment also occurs sporadically during the Late Bronze Age (in banded plates) and seems never to disappear completely from the ceramic production. It would become very common again in the Iron Age II and III in combination with the standardisation of shapes. ${ }^{30}$

\section{Mixing and Serving:}

Kraters are present in all assemblages, in smaller quantities than the bowls. The width of their opening (more than $20 \mathrm{~cm}$ ) and their capacity are the criteria employed to select them as possible mixing containers, perhaps for wine. ${ }^{31}$ Considering that none of the fragments

\footnotetext{
${ }^{25}$ Horowitz in press, fig. 6:1-3, 6 .

26 The bowl with straight rim is also called the "Mitannian bowl" in the analysis of the pottery from Qatna, and it was not considered typical for the Late Bronze Age local assemblage (Colantoni 2012, pl. 70:5-9). This shape is present also at Terqa (Rouault and Tommassini-Pieri 2014, fig. 17) and Nemrik (Reiche 2014, p. 303 pl. 2 n. 8, Mitanni level).

27 From Tell Bazi (Otto 2014, p. 99) to Tell Afis (Venturi 2014, p. 141) to Nemrik (Reiche 2014, p. 307).

${ }_{28}$ See for the Iron Age, Bonatz 2000, p. 90; for the Late Bronze Age, Yasur-Landau 2005, fig. 2.

29 Koehl 2017, fig. 18.1.7 (AT 19516.2).

${ }^{30}$ Pucci in press.

31 The analysis on the function and use of kraters in the Mediterranean Near East during the Late Bronze Age has clearly shown that besides their practical use in drinking sets, they also fulfilled a symbolic function
} 
found in these contexts provides us with a complete profile, their morphological distinctions are mainly based on the shape of the rim and of the upper body part; these allow a general reconstruction of the shapes. It is possible to distinguish three main body shapes, which are, from the narrowest to the most open: the amphoroid krater, the biconical krater and the bell-shaped krater. A cylindrical collar and a biconical body characterise the first shape (Fig. 3a), while a simple biconical body without collar is typical for the second shape (Fig. 3b and c, Fig. 4c and d). The third shape is completely open, and the body has no carination, but is bell-shaped (Fig. 4a).

V. Amphoroid Krater (BIKR-AM): a flat triangular rim with a vertical loop handle attached directly to it, a cylindrical collar and possibly a middle simple carination characterise this specific shape (Figs $3 \mathbf{a}$ and $\mathbf{4 b}$ ). The few fragments found in the stratified contexts of this square are limited to the Iron Age local phases. No surface treatment could be identified; the capacity calculated on the reconstructed vessels ranges around 361 , or 261 when filled to just above the carination.

Mycenaean amphoroid kraters (Furumark shape FS 53) were sporadic in the Late Bronze Age assemblage at Atchana: ${ }^{32}$ these kraters have an outward-curving upper part, and, in some examples, they seem already to be a combination of a biconical and an amphoroid krater. However, it is well known that Mycenaean imported kraters were ubiquitous in the northern Levant during the Late Bronze Age ${ }^{33}$ and probably contributed to defining the shape of the Iron Age examples; in fact, the handled variety occurs only in the final stages of the Late Bronze Age, and would be improved during the Iron Age. By contrast, the sharp, thickened rim seems to be more common in the Iron Age assemblages, while in the few examples from the Late Bronze Age, Alalakh kraters show a slightly offset rim, which disappears in the Iron Age. Moreover, the Iron Age versions bear features which are definitely Levantine: they are broader and squatter than their Late Bronze II counterparts.

VI. Hole-mouth Krater (HMKR): a folded-out (triangular in section) or hammer-shaped rim with a middle soft carination and no collar is typical of this shape, which is very common in the assemblage (Figs $3 \mathbf{b}$-c, $4 \mathbf{c}-\mathbf{d}$ ). They may contain from around 201 to $35 \mathrm{l}$, and their opening width ranges between 40 and $50 \mathrm{~cm}$. Iron Age hole-mouth kraters differ from the Late Bronze II kraters: their body is hemispherical and not upside-down piriform as in the Late Bronze Age; in addition, during the Iron Age the opening becomes narrower and the body squatter and more carinated. ${ }^{34}$ The Alalakh examples differ from the Mycenaean ring based kraters (FS 282) only in the fact that they are wider and shorter than their Mycenaean counterparts, but the rounded body probably imitates the Mycenaean examples. ${ }^{35}$ Figures $3 \mathrm{~b}$ and $3 \mathrm{c}$ show the similarities

\footnotetext{
(see Steel 2013, p. 88). Wine production has been suggested for the Late Bronze Age in the Levant, see Joffe 1998, Yasur-Landau 2005 and, more generally, McGovern et al. 1996.

${ }^{32}$ Horowitz in press: fig. 8:1-3.

33 Steel 2013.

${ }^{34}$ Horowitz in press: fig. 8:4.

35 Mycenaean ring base kraters were found at Ugarit Late Bronze II (Monchambert 2004a, fig. 3:1), although they are rarer than the amphoroid ones (Yon et al. 2000).
} 
between an imitation of a painted Mycenaean ring base $\mathrm{krater}^{36}$ and an unpainted one.

VII. Bell-shaped krater (KR_Bell): a large open vessel with thickened outward-curving rim and simple bell-shaped body (Fig 4a) is also part of the assemblage. The general shape follows the same type as the Mycenaean bell-shaped deep bowls (FS 285), only the dimensions are much bigger. They contain around 81 , and the opening ranges between 30 and $40 \mathrm{~cm}$. They make their first appearance in the Iron Age at the same time as the bell-shaped bowls and should be interpreted as a variant of these.

Most of the kraters from these contexts are unpainted, contain between 8 and $35 \mathrm{l}$, and have openings wide enough to allow a bowl to be dipped inside.

No single fragment could be identified in the repertoire as belonging to possible serving vessels or serving tools; that is, objects which could be employed to pour the liquid from a larger container to a cup or bowl. The two fragments of dippers presented by Koehl ${ }^{37}$ were discovered in other areas of the settlement and seem to be a very rare find. Small jars or bottles, which could also be used for direct drinking, were not identified in the assemblage from this phase. Therefore, it seems likely that liquid was drunk using single-portion bowls, and that the bowls were dipped directly into the kraters to take the liquid. It is not possible at the moment to state whether a single-portion bowl was shared on occasion of communal drinking, or if it should be considered a personal tool.

\section{Products}

Although beer and wine had been produced in Mesopotamia and Syria since the third millennium BC, evidence for the kind of liquids employed in consumption in the Iron Age assemblage from Tell Atchana is very scant. ${ }^{38}$ The archaeological data allow only a few observations. Although beer was the most common product in the Late Bronze Age, ${ }^{39}$ strainer bowls and strainer straws are extremely rare in the analysed Iron Age assemblages: in Square 42.10, only one filter bowl was identified in a later context and one metal filter was identified in Local Phase 3b. Other vessels which are considered to be specifically for beer production are completely absent. ${ }^{40}$ By contrast, a large pilgrim flask was recovered from the assemblage (Fig. 5): the shape is asymmetrical, and the vessel could contain up to 71 and belongs to a well-known Late Bronze Age type. ${ }^{41}$ These large vessels have been interpreted as possible vehicles for the transport of wine from the Karkemish area, ${ }^{42}$ so its presence in the Iron Age occupation, together with large kraters, may suggest the consumption of that beverage.

36 See Montesanto this volume, fig. 2.1.

37 Koehl 2017, fig. 18.4 n. 2 and 3.

38 Zettler and Miller 1996; McGovern 2009.

39 Milano 1994; Zarnkow et al. 2006.

${ }^{40}$ So-called beer jars or perforated jars are usually considered part of beer production. See Stol 1994; Otto 2012.

41 Venturi 1996

42 Gates 1988, pp. 71-73; Otto 2006, p. 96. 
Change and Continuity in Drinking habits from the Late Bronze Age II to the Iron Age I AT ATCHANA AND IN THE NORTHERn LEVANT

The drinking set from Late Bronze Age Alalakh includes, besides the small hemispherical bowls, which continue into the Iron Age, cylindrical cups and strainer bowls. Small cylindrical cups with outward-curving or tapered rims $\mathrm{s}^{43}$ could be employed for direct drinking; their recurrence seems to suggest that they were part of the Late Bronze Age drinking set. Larger versions of this shape (goblets) bear a painted banded decoration and belong to the wellknown group of Banded/Khabour ware, which was identified across a large geographic area in the northern Syrian and Mesopotamian regions during the Late Bronze I and II; the smaller ones with tapered rim bear a painted Atchana/Nuzi decoration. These specific shapes completely disappear in the usual sets of the Iron Age, implying the disappearance of the practice related to them. During the Iron Age, single-portion bowls, by contrast, increase in number and morphological diversity, with variations in decoration and capacity: besides the typical local bowl shapes, Aegeanising ones, such as bell-shaped bowls and angular shallow bowls, were introduced into the repertoire. The predominance of bowls over cups and goblets may be related to the way liquids (or specific liquids) were consumed, this time directly from the bowls. The same absence can be noted for the strainer bowls (and conical metal strainers) which were present in the Late Bronze II assemblage at Atchana and elsewhere; ${ }^{44}$ this may suggest that during the Iron Age, direct drinking from a large vessel (as the metal filters seem to indicate) disappeared, while filters were directly applied to small jars.

Looking at a broader geographic area, if we compare the Iron Age drinking set from Atchana with Late Bronze Age assemblages from other sites, we can point out further differences. Although Late Bronze II in situ drinking sets from primary contexts are not available at sites from the northern Levant, Ugarit and Tarsus offer a very large repertoire, especially for the very late phases of the Late Bronze Age, which are ephemeral at Atchana. The presence of Aegeanising shapes in the Late Bronze Age assemblages at both Tarsus and Ugarit seem to influence the drinking sets; amphoroid kraters (FS53-55), handled cups (FS 220-222), kylixes (FS 258, 267 and 274) and shallow angular bowls (FS 284) are common shapes employed and imported to the Levantine coast, and these shapes are all involved in drinking. ${ }^{45}$ Stemmed bowls (kylixes and stemmed cups), which were characteristic in the Aegean archaeological evidence and Aegean representations of drinking activities, ${ }^{46}$ are few among the Mycenaean imports in the northern Levant and are completely absent from the Iron Age assemblage. This implies that the kind of bowl and the way it was held remained unvaried from the Late Bronze Age local tradition and the few stemmed Mycenaean imports did not influence the drinking or toasting habits at Alalakh. ${ }^{47}$

\footnotetext{
${ }^{43}$ Horowitz in press, figs 11:1-2, 16:1-5. The function of the larger cylindrical cups has been debated. It should, however, be pointed out that the smaller ones seem to be related to drinking activity (see Stein 1984).

${ }_{44}$ Otto 2014, p. 100; Horowitz in press, fig. 7:1-2, 7; Badre and Capet 2014, p. 165.

45 Ugarit (Monchambert 2004a, N2, fig. 5 no. 18, fig. 1 no. 19; 2004b, figs 20-23); Kazel (Jung 2011); Megiddo (Leonard and Cline 1998). See also Wijngaarden 2002, p. 114.

46 Yasur-Landau 2005, pp. 172-174; Wright 2004a.

47 See Koehl 2017, table 18.1
} 
Thus, the only Mycenaeanising shapes which seem to be used and produced in Iron Age Atchana are the bell-shaped kraters and the shallow angular bowl. It is, however, interesting that these two shapes were not the most common in the Late Bronze Age repertoires, nor do they preserve in the Iron Age the typical decorative features of the Late Bronze Age imports. The introduction of shallow angular bowls among the locally produced simple ware may be related to different factors: first, the appearance of local imitations of specific Mycenaean shapes (mainly bell-shaped bowls and amphoroid kraters, and more rarely, cooking pots) is common in the early Iron Age Levant and reflects, in the case of the Amuq region, a profound Mycenaean ascendancy, which has been explained in various ways (migration, invasion, influence) and will not be discussed here. Second, specifically the shallow angular bowls are similar in their general shape and size to the locally produced hemispherical bowls with outward-curving rim, so they could easily have been introduced into the local repertoire without implying a different handling of the cup itself. ${ }^{48}$ Painted decoration does not disappear completely during the Iron Age (as it is attested in later contexts of Square 42.10 and in Square 32.42); it represents, however, a very small percentage of the repertoire and was applied, besides the bell-shaped bowls, mainly to kraters. ${ }^{49}$

The morphological changes which concern the kraters and have been described above could already be identified during the very end of the Late Bronze Age and do not seem to affect the function of the vessels. Therefore, considering both direct-drinking and serving vessels, a strong continuity from the Late Bronze Age can be observed in the drinking sets, together with the progressive disappearance during the Iron Age of specific shapes (locally produced as beakers and cups or imported in forms such as kylixes). This disappearance could be related to the drinking of specific products (as with the cylindrical cups) and/or to a different social context.

\section{Drinking IN THE EARLy IRON Age IN THE NORTHERn LEVANT}

Thus, the Iron Age I drinking set seems to be restricted to a few main shapes: single-sized bowls and multiple-serving kraters, in which specific drinks were mixed. It seems likely that the same bowls could be employed to drink liquids which did not require mixing (such as water) from large storage containers. Cups and other drinking tools (such as dippers or filters) or specialty vessels (such as stirrup jars, strainer jugs and feeding bottles) are completely missing from the Early Iron Age repertoire at Atchana. This reduced drinking set finds good comparisons with pottery inventories from the 12th century BC in the northern Levant.

\footnotetext{
48 The addition of the handles follows a general trend of the Iron Age: during this period, handles were always applied to kraters and jars, and sometimes to bowls, to storage jars and to cooking pots. While their application on the cooking pots also meant a practical change (once vertical handles began to be applied on the pots, the collar, which was typical for the Late Bronze Age assemblage and useful in handling the pot, became completely useless), in other examples, the handles were only vestigial (in several shallow angular bowls) or not useful (as is the case for the storage jars).

${ }_{49}$ Montesanto this volume, fig. 2.6.
} 
Simple hemispherical bowls or hemispherical bowls with straight rim were found at Tell Afis, Chatal Höyük, Tell Arqa (together with hemispherical bowls), Tell Tweini and Tell Tayinat. ${ }^{50}$ The same can be observed for the imitations of shallow angular bowls (mostly unpainted), which are present at Kazel in the passage from the Late Bronze Age to the Iron Age, ${ }^{51}$ at Tarsus, at Tell Afis and in the southern Levant. ${ }^{52}$ By contrast, the small bowls (BWL_MIN) are extremely scarce in early Iron Age contexts from neighbouring sites, ${ }^{53}$ so they may mirror the persistence of a Late Bronze Age tradition specifically at Alalakh. The fact that the examples presented here are all from the very early phase (Local Phase 3b) of Square 42.10 seems to confirm this statement.

Amphoroid and biconical kraters, although different in shape, share similar dimensions (capacity and width of the opening), while the bell-shaped kraters are smaller both in their opening and in their capacity and may have had a different use. At Chatal Höyük, the amphoroid krater in its Levantine version becomes very popular over time and more common than the simple biconical krater, which continues being produced but tends to disappear over time. ${ }^{54}$ The Alalakh assemblage presented here shows the very first stages of this transformation, when the hole-mouth krater is still more numerous and the local amphoroid kraters are making their first appearance. All three shapes are well known in the Iron Age assemblages from the northern Levant, ${ }^{55}$ and are part of the drinking sets for this region. Although in the northern Levant kraters are among the shapes which are more frequently painted, all kraters found in this assemblage at Tell Atchana were unpainted; this could suggest that the Early Iron Age context, at least in this area and in its beginning phases, was quite poor.

Moreover, the drinking set as it has been identified at Alalakh seems to be common in a very large area in the Amuq and north Syria, but already at sites east of the Euphrates, the drinking set of the Early Iron Age occupation consisted of carinated bowls and several jugs, and different kinds of drinking sets were employed. ${ }^{56}$ More extensively excavated sites, such as Chatal Höyuk, Tell Tayinat and Tell $\mathrm{Afis}^{57}$ in the northern Levant provided larger assemblages, but not richer ones in terms of shapes related to drinking activity, so we may

50 Venturi 2007, fig. 56:9-11 (Tell Afis); Pucci in press, pl. 63a-c (Chatal Höyük); Charaf 2011, fig. 3:4 (Tell Arqa); Du Piêd 2011, fig. 10e (Tell Tweini); Harrison 2013, fig. 5.10 (Tell Tayinat).

51 Jung (2011) states that 5 per cent of the Mycenaeanising pottery from the site belongs to this shape.

52 French 1975, fig. 16 (Tarsus); Venturi 2007, fig. 572 (Tell Afis); Killebrew and Lev-Tov 2008 (southern Levant).

53 Possibly one from Tayinat: Harrison 2013, fig. 2 no. 3.

54 This process of transformation could be observed at Chatal Höyük (Pucci in press) and on a smaller scale at Tell Tayinat: here the amphoroid kraters are, in Field Phase 5, more numerous than the biconical ones (see Janeway 2013, pls. 7-9).

55 Besides the examples from Tayinat, kraters in all three shapes were found at Ras Ibn Hani (see Du Piêd 2006-07, fig. 7), at Tell Afis (Venturi 2007, figs 58.9, 49.8, 11, 49.1-5); amphoroid and biconical (Badre 2006, fig. 13) at Tell Kazel, at Tell Tweini (Vansteenhuyse 2010, Ill.3) and at Tille Höyük (Blaylock 1999, fig. 99).

56 It is quite difficult to point to drinking sets in this area which can be dated with certainty to the beginning of Iron Age I (12th-10th century BC) on the east side of the Euphrates in order to make comparisons in the same chronological period. Tille Höyük, for example, already shows shapes for direct drinking different from those at Atchana, see Blaylock 2016, fig. 11.5. Possibly Jurn al Kabir and Lidar Höyük provide the best examples.

57 Venturi 2007, fig. 57.6. 
hypothesise a general trend in the Early Iron Age northern Levant. The absence of specialty vessels such as beer strainers and feeding bottles, filters and beakers, emphasised above, is also attested at other neighbouring and contemporary sites in these early levels of the northern Levant.

\section{CONCLUSIONS}

The archaeological evidence at Tell Atchana related to drinking habits shows a strong continuity and some changes from the Late Bronze Age assemblage: cups disappear, single serving bowls were employed for direct drinking and were filled through direct immersion in large kraters, and handles start to become ubiquitous on open vessels. Although at Atchana these changes could be related to the limited extent of excavations and, consequently, to the different nature of the excavated contexts (such as Late Bronze Age palace and household inventories on the one hand, and Iron Age open areas on the other), they seem to occur also at other sites in the northern Levant, and, consequently, they may mirror a general trend. The same phenomena are attested in the Iron Age levels at other sites in the Amuq (such as Chatal Höyük and Tell Tayinat) or inner Syria (such as Tell Afis, Tell Kazel and Tell Qarqur). They can consequently be regarded as concerning the whole northern Levant, mirroring a slow but progressive change in the morphology of drinking sets, but not in the performance of the action.

The archaeological material at our disposal does not currently allow us to reconstruct the product consumed in this set; however, the disappearance of filters as well as the use of the kraters (biconical or amphoroid) may indicate that wine continued being consumed. It remains for the moment a working hypothesis which needs to be tested in other assemblages.

Moreover, the introduction of Mycenaeanising shapes in the drinking set does not imply the introduction of Mycenaean drinking habits: Mycenaean habits are related to specific handling of the containers employed for direct drinking (usually the kylix) and to specific content, usually related to specialty vessels which are not part of the set found at Tell Atchana. The modification of the shape of the local krater, as well as the introduction of the imitation of the shallow angular bowls and bell-shaped bowls are possible clues for hypothesising a progressive fusion, a melting of different cultural elements, in which the local tradition remained the stronger one. 


\section{CATALOGUE}

Fig. 1a

Inv. Nr.: AT 19586.4

Context: Area 1, Sq. 42.10, Locus 23, Context 204, Local Phase 3b

Shape description: Miniature shallow bowl with straight vertical rim. BWL_Min

Fabric: Simple Ware, tan

Surface Treatment/Decoration: None

Fig. 1b

Inv. Nr.: AT 19593.1

Context: Area 1, Sq. 42.10, Locus 20, Context 203, Local Phase 3b

Shape description: Miniature shallow bowl, flat base. BWL_Min

Fabric: Simple Ware, salmon

Surface Treatment/Decoration: None

Fig. 1c

Inv. Nr.: AT 20038.2

Context: Area 1, Sq. 42.10, Locus 24, Context 204, Local Phase 3b

Shape description: Miniature hemispherical bowl, rounded base. BWL_Min

Fabric: Simple Ware, tan

Surface Treatment/Decoration: None

Fig. 1d

Inv. Nr.: AT 20048.1

Context: Area 1, Sq. 42.10, Locus 24, Context 203, Local Phase 3b

Shape description: Shallow bowl, truncated cup. Out-curving rim. BWL_Min

Fabric: Simple Ware, salmon

Surface Treatment/Decoration: None

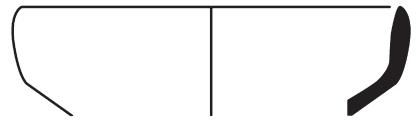

a) AT19586.4

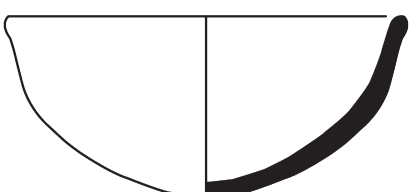

c) AT20038. 2

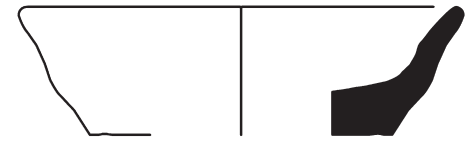

b) AT19593.1
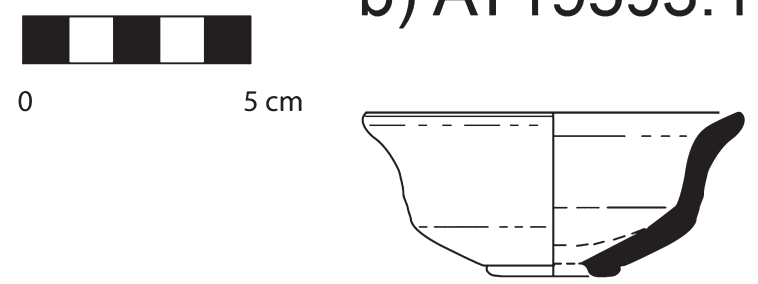

d) AT20048.1

Fig. 1. Miniature bowls from Square 42.10, Local Phase 3 (Iron Age I) 
Fig. 2a

Inv. Nr.: AT 19545.5

Context: Area 1, Sq. 42.10, Locus 20, Context 204, Local Phase 3b

Shape description: Hemispherical bowl with horizontal loop handle. Imitation of shallow angular bowl. CABL

Fabric: Simple Ware, cream

Surface Treatment/Decoration: None

Fig. 2b

Inv. Nr.: AT 19461.9

Context: Area 1, Sq. 42.10, Locus 16, Context 163, Local Phase 3a

Shape description: Hemispherical bowl, outward curving rim. CABL

Fabric: Simple Ware, cream

Surface Treatment/Decoration: None

Fig. 2c

Inv. Nr.: AT 19511.2

Context: Area 1, Sq. 42.10, Locus 16, Context 163, Local Phase 3a

Shape description: Hemispherical bowl with horizontal loop handle. Imitation of shallow angular bowl. CABL

Fabric: Simple Fine Ware, salmon

Surface Treatment/Decoration: None

Fig. 2d

Inv. Nr.: AT 19564.3

Context: Area 1, Sq. 42.10, Locus 16, Context 164, Local Phase 3a

Shape description: Hemispherical bowl with horizontal loop handle. Imitation of shallow angular bowl. CABL

Fabric: Simple Ware, tan

Surface Treatment/Decoration: None

Fig. 2e

Inv. Nr.: AT 19569.1

Context: Area 1, Sq. 42.10, Locus 22, Context 204, Local Phase 3b

Shape description: Hemispherical Bowl, vertical tapered rim. BWL_Hem

Fabric: Simple Ware, grey

Surface Treatment/Decoration: None

Fig. 2f

Inv. Nr.: AT 20016.2

Context: Area 1, Sq. 42.10, Locus 20, Context 203, Local Phase 3b

Shape description: Hemispherical bowl, tapered rim. BWL_Hem

Fabric: Simple Ware, cream

Surface Treatment/Decoration: None

Fig. $2 \mathrm{~g}$

Inv. Nr.: AT 19511.3

Context: Area 1, Sq. 42.10, Locus 16, Context 162, Local Phase 3a 
Shape description: Hemispherical bowl, vertical rim. BWL_Hem

Fabric: Simple Ware, tan

Surface Treatment/Decoration: None

\section{Fig. $2 \mathrm{~h}$}

Inv. Nr.: AT 19532.4

Context: Area 1, Sq. 42.10, Locus 20, Context 203, Local Phase 3b Shape description: Hemispherical bowl, rolled out rim. HEBL_FL

Fabric: Simple Fine Ware, cream

Surface Treatment/Decoration: None

Fig. 2i

Inv. Nr.: AT 19529.2

Context: Area 1, Sq. 42.10, Locus 16, Context 163, Local Phase 3a

Shape description: Shallow bowl, concave base, rilling on the exterior. BWL_Hem

Fabric: Simple Ware, cream

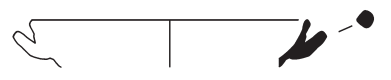

a) AT19545.5

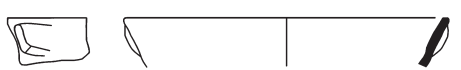

c) AT19511_2

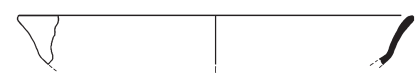

b) AT19461.9

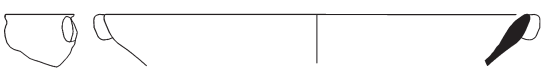

d) AT19564.3

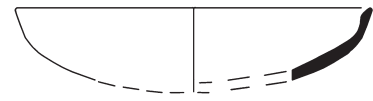

e) AT19569.1



h) AT19532.4

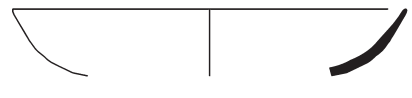

f) AT20016.2

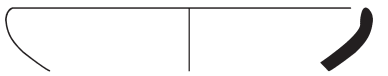

g) AT19511.3

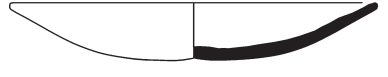

i) AT19529_2



j) AT20085.2

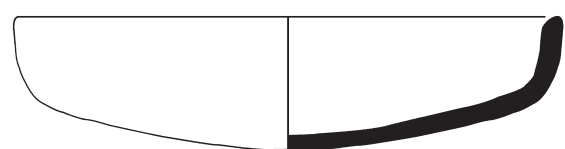

k) AT20057.1

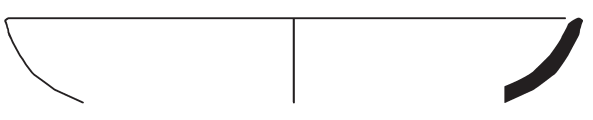

I) AT19569.2

Fig. 2. Bowls from Square 42.10, Local Phase 3 (Iron Age I): a-d, Imitation of Shallow Angular bowls; e-j, Hemispherical bowls with outcurving or straight rim, for drinking; k-l, Larger hemispherical bowls with outcurving or straight rim 
Surface Treatment/Decoration: None

Notes: These specific bowls with the rilling on the external base are very common in Late Bronze Age assemblages.

Fig. 2 j

Inv. Nr.: AT 20085.2

Context: Area 1, Sq. 42.10, Locus 24, Context 203, Local Phase 3b

Shape description: Shallow bowl, straight rim. BWL_Str

Fabric: Simple Ware, salmon

Surface Treatment/Decoration: None

Fig. $2 \mathrm{k}$

Inv. Nr.: AT 20057.1

Context: Area 1, Sq. 42.10, Locus 20, Context 203, Local Phase 3b

Shape description: Shallow bowl, straight rim. BWL_Str

Fabric: Simple Ware, tan

Surface Treatment/Decoration: None

Fig. 21

Inv. Nr.: AT 19569.2

Context: Area 1, Sq. 42.10, Locus 22, Context 204, Local Phase 3 b

Shape description: Shallow bowl. BWL_Str

Fabric: Simple Ware, tan

Surface Treatment/Decoration: None

Fig. 3a

Inv. Nr.: AT 18327.2

Context: Area 1, Sq. 42.10, Locus 12

Shape description: Amphoroid krater. BIKR-AM

Fabric: Simple Ware, cream

Surface Treatment/Decoration: None

Notes: Reconstruction

Fig. 3b

Inv. Nr.: AT 14906.2

Context: Area 1, Sq. 32.42, Locus 9

Shape description: Hole-mouth krater, ring base krater. HMKR

Fabric: Painted Ware

Surface Treatment/Decoration: Horizontal bands and zigzag, red paint

Notes: Reconstruction

Fig. 3c

Inv. Nr.: AT 20085.4

Context: Area 1, Sq. 42.10, Locus 24

Shape description: Hole-mouth Krater. HMKR

Fabric: Simple Ware, tan

Surface Treatment/Decoration: None

Notes: Reconstruction: the base is left rounded, although most probably it had a ring base. 


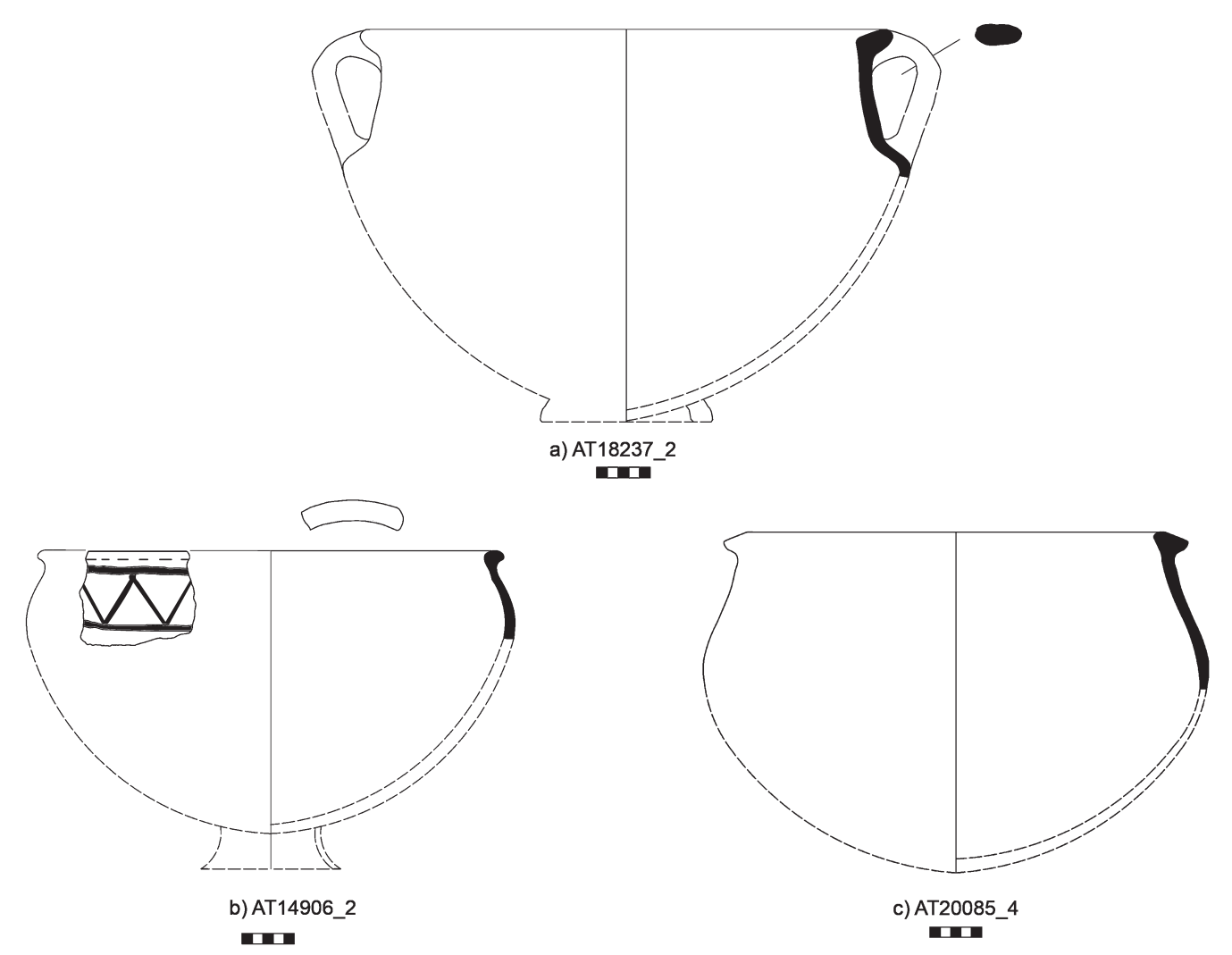

Fig. 3. Reconstruction drawings of main kraters' shapes: a) Amphoroid Krater, b) Hole-mouth Krater, ring base type, c) Hole-mouth Krater

Fig. 4a

Inv. Nr.: AT 20007.1

Context: Area 1, Sq. 42.10, Locus 20, Context 203, Local Phase 3b

Shape description: Krater, bell-shaped. KR_Bell

Fabric: Simple Ware, tan

Surface Treatment/Decoration: None

Fig. $4 b$

Inv. Nr.: AT 19572.10

Context: Area 1, Sq. 42.10, Locus 23, Context 204, Local Phase 3b

Shape description: Amphoroid krater. BIKR-AM

Fabric: Simple Ware, cream

Surface Treatment/Decoration: None

Fig. 4c

Inv. Nr.: AT 20085.4

Context: Area 1, Sq. 42.10, Locus 24, Context 203, Local Phase $3 b$

Shape description: Hole-mouth krater. HMKR

Fabric: Simple Ware, tan

Surface Treatment/Decoration: None 


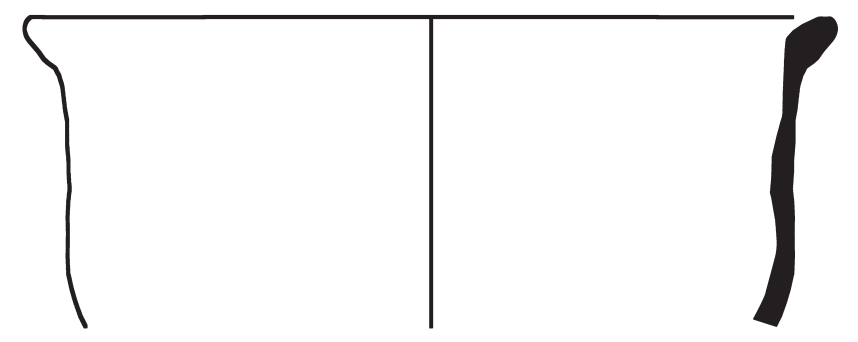

a) AT20007.1

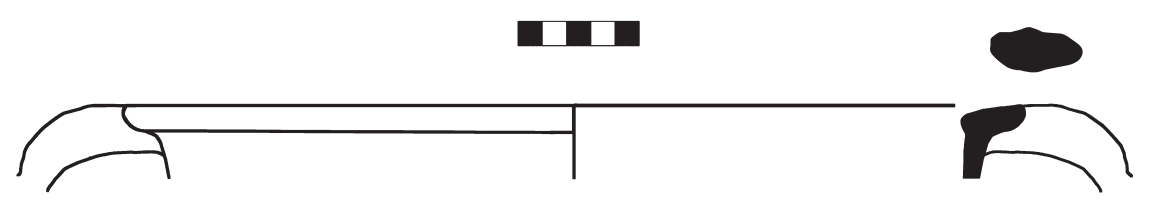

b) AT19572.10

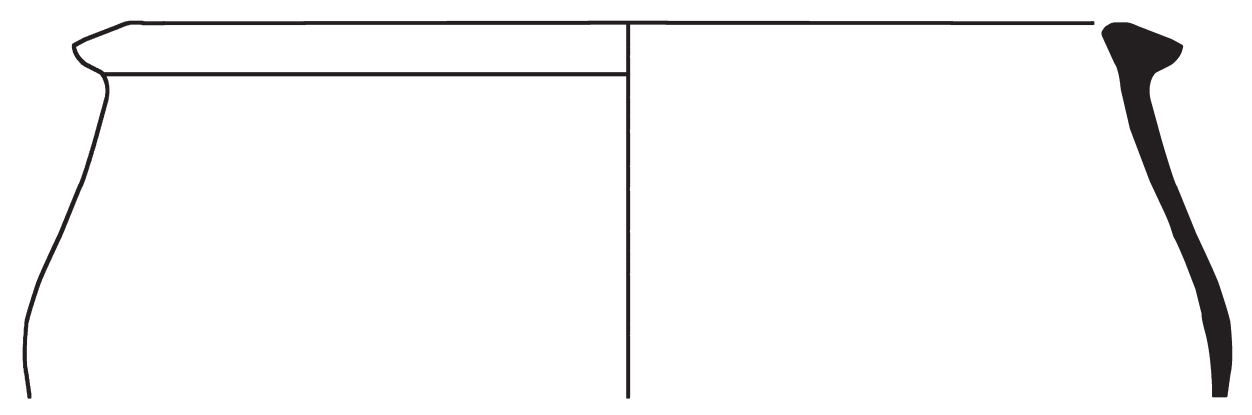

c) AT20085.4

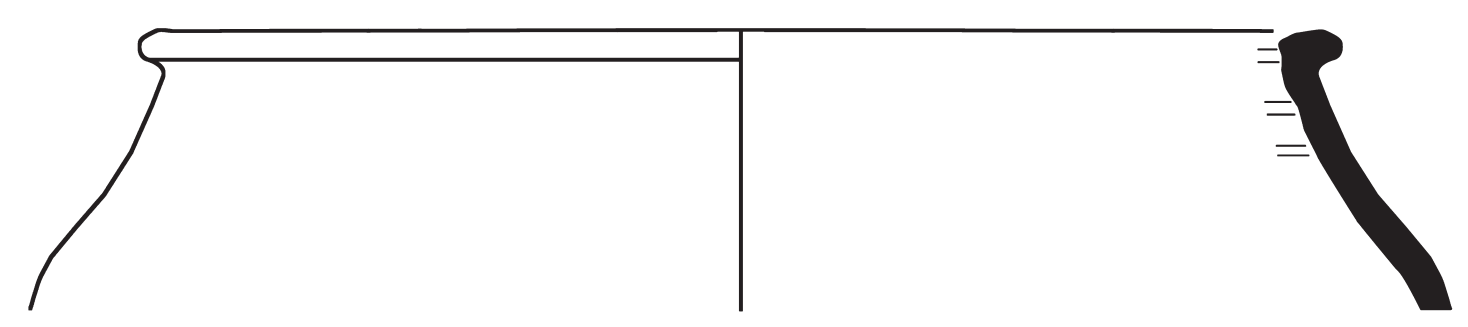

d) AT19572.11

口0

Fig. 4. Kraters from Square 42.10 Local Phase 3 (Iron Age I): a) Bell-shaped Krater,

b) Amphoroid Krater, c-d) Hole-mouth Kraters 
Fig. 4d

Inv. Nr.: AT 19572.11

Context: Area 1, Sq. 42.10, Locus 23, Context 204, Local Phase 3b Shape description: Hole-mouth krater. HMKR

Fabric: Simple Ware, cream

Surface Treatment/Decoration: None

Fig. 5

Inv. Nr.: AT 20016.3

Context: Area 1, Sq. 42.10, Locus 20, Context 203, Local Phase 3b Shape description: Pilgrim Flask, asymmetrical.

Fabric: Simple Ware, cream

Surface Treatment/Decoration: None

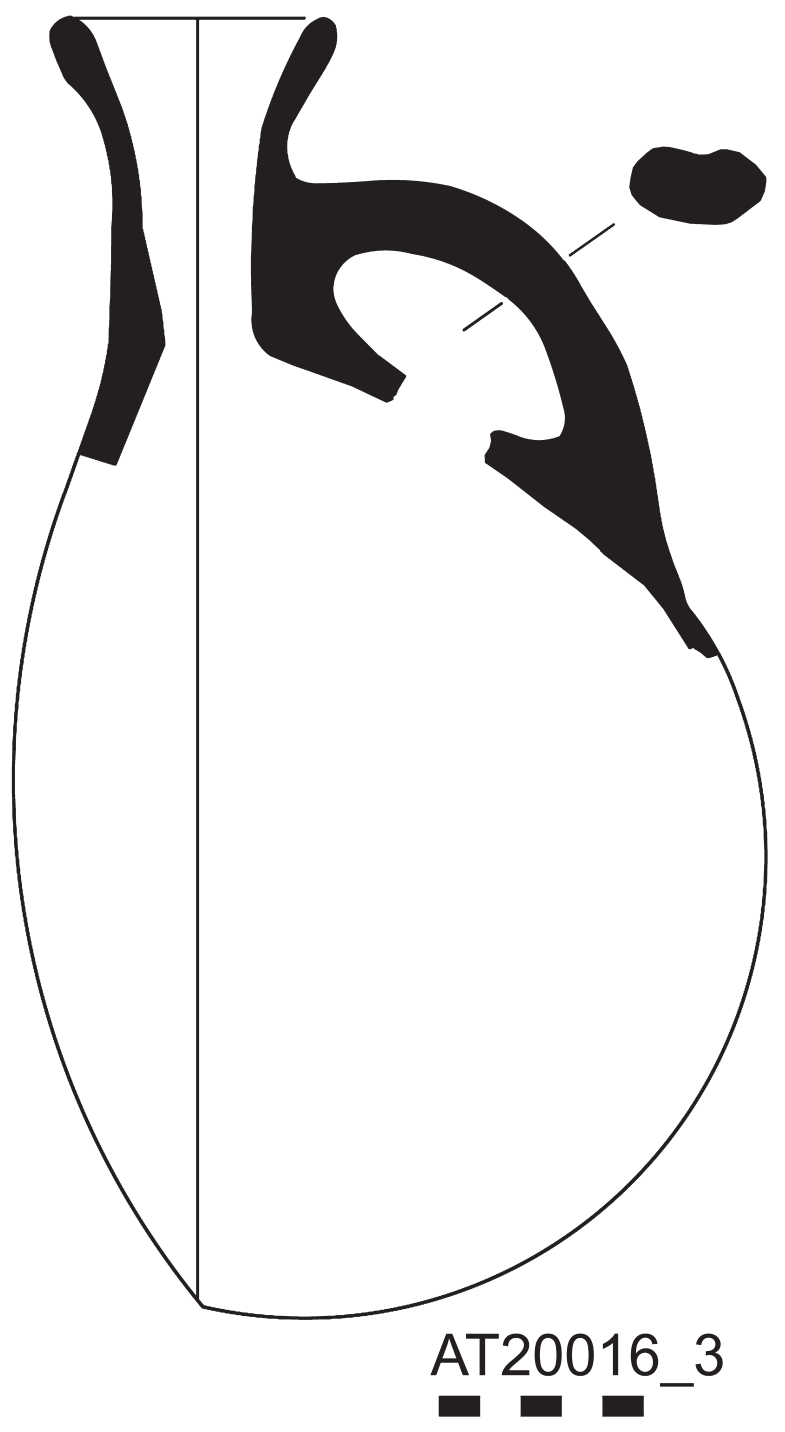

Fig. 5. Pilgrim Flask from Square 42.10 Local Phase 3 (Iron Age I) 
BIBLIOGRAPHY

AKAR, M.

2013 "The Late Bronze Age fortresses at Alalakh: Architecture and identity in Mediterranean exchange systems," in Across the Border: Late Bronze-Iron Age Relations between Syria and Anatolia, Proceedings of a Symposium Held at the Research Center of Anatolian Studies, Koç University, Istanbul, May 31-June 1, 2010 (Ancient Near Eastern Studies 42), edited by K. A. Yener, pp. 37-60. Leuven: Peeters.

BADRE, L.

2006 "Tell Kazel - Simyra: A contribution to a relative chronological history in the Eastern Mediterranean during the Late Bronze Age," Bulletin of the American Schools of Oriental Research 343: 65-95.

BADRE, L. and CAPET, E.

2014 "The Late Bronze Age pottery from Tell Kazel: Links with the Aegean, Cyprus, and the Levant," in Recent Trends in the Study of Late Bronze Age Ceramics in SyroMesopotamia and Neighbouring Regions, edited by A. Hausleiter and M. Luciani, pp. 157-180. Rahden: Marie Leidorf.

Badre, L., Gubel, E., Capet, E. and Panayot, N.

1994 "Tell Kazel (Syrie). Rapport préliminaire sur les 4e-8e campagnes de fouilles (19881992)," Syria 71: 259-346.

Batiuk, S. and Horowitz, M. T.

2010 “Temple Deep Sounding investigations, 2001-2006," in Tell Atchana, Ancient Alalakh Volume 1: The 2003-2004 Excavations Seasons, edited by K. A. Yener, pp. 161-176. Istanbul: Koç University Press.

BIKAI, P. M.

1978 The Pottery of Tyre. Warminster: Aris and Phillips.

BLAYLOCK, S. R.

1999 "Iron Age pottery from Tille Höyük, South-Eastern Turkey," in Iron Age Pottery in Northern Mesopotamia, Northern Syria, and South-Eastern Anatolia: Papers Presented at the Meetings of the International 'table ronde' at Heidelberg (1995) and Nieborów (1997) and other Contributions, edited by A. Hausleiter and A. Reiche, pp. 263-286. Münster: Ugarit-Verlag.

2016 Tille Höyük 3.2. The Iron Age, Pottery Objects and Conclusions (British Institute of Archaeology at Ankara Monograph 50). London: British Institute of Archaeology at Ankara.

BONATZ, D.

2000 Das syro-hethitische Grabdenkmal: Untersuchungen zur Entstehung einer neuen Bildgattung in der Eisenzeit im nordsyrisch-südostanatolischen Raum. Wiesbaden: Harrassowitz.

BRAY, T. L., ed.

2003 The Archaeology and Politics of Food and Feasting in Early States and Empires. New York: Kluwer Academic/Plenum.

CHARAF, H.

2011 "Over the hills and far away: Handmade Burnished Ware and Mycenaean cooking pots at Tell Arqa, Libanon," in On Cooking Pots, Drinking Cups, Loomweights and Ethnicity in Bronze Age Cyprus and Neighbouring Regions (an International Archaeological Symposium held in Nicosia, November 6th-7th 2010), edited by V. Karageorghis Colantoni, C. and O. Kouka, pp. 203-218. Nicosia: Leventis.

2012 The Late MBA and LBA Pottery Horizons at Qatna. Udine: Forum.

Courtois, J. C.

1969 "Le matériel céramique de la tombe 4253 du Bronze Récent à Ugarit," in Ugaritica VI, edited by C. F. A. Schaeffer, pp. 121-138. Paris: Geuthner. 
Dietler, M. and Hayden, B., eds.

2001 Feasts: Archaeological and Ethnographic Perspectives on Food, Politics, and Power. Washington, DC: Smithsonian Institution Press.

Du PIÊD, L.

2006-07 "The Early Iron Age in the Northern Levant: Continuity and change in the pottery assemblages from Ras el-Bassit and Ras Ibn Hani," Scripta Mediterranea 27-28: 161-186.

2011 "Early Iron Age society in the northern Levant: Architecture, pottery and finds," in On Cooking Pots, Drinking Cups, Loomweights and Ethnicity in Bronze Age Cyprus and Neighbouring Regions (an International Archaeological Symposium held in Nicosia, November 6th-7th 2010), edited by V. Karageorghis and O. Kouka, pp. 219-236. Nicosia: Leventis.

FINK, A. S.

2010 Late Bronze Age Tell Atchana (Alalakh): Stratigraphy, Chronology, History. Oxford: Archaeopress.

Fortin, M., CoOper, L. and Boileau, M. C.

2014 "Rapport préliminaire et études céramologiques sur les campagnes de fouilles 2009 et 2010 à Tell 'Acharneh, vallée du Ghab, Syrie," Syria 91: 173-220.

FRENCH, E. B.

1975 “A reassessment of the Mycenaean pottery at Tarsus," Anatolian Studies 25: 53-75.

FURUMARK, A.

1941 Mycenaean Pottery: 1. Analysis and Classification. 2. Chronology. 3. Plates. Stockholm: Svenska Institutet i Athen.

GATES, M.-H.

1988 "Dialogues between Ancient Near Eastern texts and the archaeological record: Test cases from Bronze Age Syria," Bulletin of the American Schools of Oriental Research 270: 63-91.

HARRISON, T. P.

2013 "Tayinat in the Early Iron Age," in in Across the Border: Late Bronze-Iron Age Relations between Syria and Anatolia, Proceedings of a Symposium Held at the Research Center of Anatolian Studies, Koç University, Istanbul, May 31-June 1, 2010 (Ancient Near Eastern Studies 42), edited by K. A. Yener, pp. 61-87. Leuven: Peeters.

HitchCock, L., LAFFineur, R. and Crowley, J. L.

2008 Dais: The Aegean Feast: Proceedings of the 12th International Aegean Conference, $12 e$ Rencontre égéenne internationale, University of Melbourne, Centre for Classics and Archaeology, 25-29 March 2008. Liège: Université de Liège.

HOROwITZ, M. T.

In press "Local ceramics in the battleground of empires: Alalakh in the $14^{\text {th }}$ Century BC", in Ceramic Identities, edited by S. Mazzoni, M. Pucci, F. Venturi. Pisa: ETS.

JANEWAY, B.

2013 Cultural Transition in the Northern Levant during the Early Iron Age as Reflected in the Aegean-Style Pottery at Tell Tayinat. Unpublished Ph.D. diss. University of Toronto.

JUNG, R.

2011 "Mycenaean vending cups in Syria? Thoughts about the unpainted Mycenaean pottery from Tell Kazel," in Our Cups Are Full: Pottery and Society in the Aegean Bronze Age Papers Presented to Jeremy B. Rutter on the Occasion of his 65th Birthday, edited by W. Gauss, M. Lindblom, R. A. K. Smith and J. C. Wright, pp. 121-132. Oxford: Archaeopress.

KARAGEORGHIS, V.

2007 "Eating and drinking in Cyprus, $13^{\text {th }}-6^{\text {th }}$ centuries B.C.," in Keimelion: Elitenbildung und elitärer Konsum von der mykenischen Palastzeit bis zur homerischen Epoche: Akten des internatonalen Kongresses vom 3 bis 5 Februar 2005 in Salzburg, edited by E. Alram-Stern and G. Nightingale, pp. 257-262. Vienna: Verlag der Österreichische Akademie der Wissenschaften. 
Killebrew, A. and LeV-Tov, J.

2008 "Early Iron Age feasting and cuisine: An indicator of Philistine-Aegean connectivity?," in Dais: The Aegean Feast: Proceedings of the 12th International Aegean Conference, University of Melbourne, Centre for Classics and Archaeology, 25-29 March 2008, edited by L. Hitchcock, R. Laffineur and J. L. Crowley, pp. 339-346. Liège: Université de Liège.

KoEHL, R.

2017 "Were there Sea Peoples at Alalakh (Tell Atchana)?", in Overturning Certainties in Near Eastern Archaeology. A Festschrift in Honor of K. Aslihan Yener, edited by Ç. Maner, M. Horowitz and A. Gilbert, pp. 275-295. Leiden: Brill.

JOFFE, A. H.

1998 "Alcohol and social complexity in ancient western Asia," Current Anthropology 39: 297-322.

Leonard, A. and Cline, E. H.

1998 "The Aegean pottery at Megiddo: An appraisal and reanalysis," Bulletin of the American Schools of Oriental Research 309: 3-39.

Mazow, L. B.

2005 Competing Material Culture: Philistine Settlement at Tel Miqne-Ekron in the Early Iron Age. Unpublished Ph.D. diss. University of Arizona.

MAZZONI, S.

1997 "The gate and the city: Change and continuity in Syro-Hittite urban ideology," in Die Orientalische Stadt: Kontinuität, Wandel, Bruch, edited by G. Wilhelm, pp. 307338. Saarbrücken: Saarbrücker Verlag.

MCGOVERN, P. E.

2009 Uncorking the Past: The Quest for Wine, Beer, and Other Alcoholic Beverages. Berkeley; Los Angeles: University of California Press.

McGovern, P. E., Fleming, S. J. and Katz, S.

1996 The Origins and Ancient History of Wine. Amsterdam: Routledge.

MLANO, L.

1994 "Vino e Birra in Oriente. Confini geografici e confini culturali," in Drinking in Ancient Societies History and Culture of Drinks in the Ancient Near East Papers of a Symposium held in Rome, May 17-19 1990, edited by L. Milano, pp. 421-440. Padova: Sargon.

MONCHAMBERT, J.-Y.

2004a La céramique d'Ougarit: Campagnes de fouilles 1975 et 1976. Paris: Editions Recherche sur les Civilisations.

2004 b "La céramique mycénienne d'Ougarit. Nouvelles données," in La céramique mycénienne de l'Égée au Levant: Hommage à Vronwy Hankey, edited by J. Balensi, J.-Y. Monchambert and S. Müller Celka, pp. 125-140. Lyon: Maison de l'Orient et de la Méditerranée and Boccard.

NA'AMAN, N.

1980 "The Ishtar Temple at Alalakh," Journal of Near Eastern Studies 39: 209-214.

Отто, А.

2006 Alltag und Gesellschaft zur Spätbronzezeit: Eine Fallstudie aus Tall Bazi (Syrien). Turnhout: Brepols.

2012 "Defining and transgressing the boundaries between ritual commensality and daily commensal practices: The case of Late Bronze Age Tall Bazi," in Between Feasts and Daily Meals: Toward an Archaeology of Commensal Spaces, edited by S. Pollock, pp. 179-195, Berlin: Edition Topoi.

2014 "The Late Bronze Age pottery of the 'Weststadt' of Tell Bazi (Syrien)," in Recent Trends in the Study of Late Bronze Age Ceramics in Syro-Mesopotamia and Neighbouring Regions, edited by A. Hausleiter and M. Luciani, pp. 85-118. Rahden: Marie Leidorf. 
PuCCI, M.

in press Excavations in the Plain of Antioch, Volume 3. Stratigraphy and Materials from Chatal Hüyük. Chicago: Oriental Institute Publications.

RABINOWITZ, A.

2009 "Drinking from the same cup: Sparta and Late Archaic commensality," in Sparta Comparative Approaches, edited by S. Hodkinson, pp. 113-192. Swansea, Wales: The Classical Press of Wales.

ReICHE, A.

2014 "Late Bronze Age pottery from Nemrik," in Recent Trends in the Study of Late Bronze Age Ceramics in Syro-Mesopotamia and Neighbouring Regions, edited by A. Hausleiter and M. Luciani, pp. 289-332. Rahden: Marie Leidorf.

Rouault, O. and TOMmassini-Pieri, B. M.

2014 "Stratigraphy, chronology and the Late Bronze Age ceramics in Terqa and around," in Recent Trends in the Study of Late Bronze Age Ceramics in Syro-Mesopotamia and Neighbouring Regions, edited by A. Hausleiter and M. Luciani, pp. 219-234. Rahden: Marie Leidorf.

SALLES, J.-F.

1980 La nécropole $K^{\prime}$ de Byblos. Lyon: Editions Association pour la Diffusion de la Pensée Française.

SinOpoli, C. M.

1991 Approaches to Archaeological Ceramics. New York, London: Springer.

SKIBO, J. M.

Understanding Pottery Function. New York: Plenum Press.

SMITH, M. F.

1988 "Function from whole vessel shape: A method and an application to Anasazi Black Mesa, Arizona," American Anthropologist 90: 912-923.

SouTH, A.

2008 "Feasting in Cyprus: A view from Kalavasos," in Dais: The Aegean Feast: Proceedings of the 12th International Aegean Conference, University of Melbourne, Centre for Classics and Archaeology, 25-29 March 2008, edited by L. Hitchcock, R. Laffineur and J. L. Crowley, pp. 309-316, Liège: Université de Liège.

STEEL, L.

2004 "A goodly feast ... A cup of mellow wine: Feasting in Bronze Age Cyprus," Hesperia 73: 281-300.

2013 Materiality and Consumption in the Bronze Age Mediterranean. New York; London: Routledge.

STEIN, D. L.

1984 "Khabur Ware and Nuzi Ware: Their origin, relationship, and significances," Assur 4/1: 1-65.

STOL, $M$

1994 "Beer in Neo-Babylonian times," in Drinking in Ancient Societies: History and Culture of Drinks in the Ancient Near East: Papers of a Symposium Held in Rome, May 17-19, 1990, edited by L. Milano, pp. 155-183. Padova: Sargon.

VANSTEENHUYSE, K.

2010 "La ceramique du Chantier A," in Tell Tweini: Onze campagnes de fouilles Syro-Belges (1999-2010), edited by M. Al-Maqdissi, K. Van Lerberghe, J. Bretschneider and M. Badawi, pp. 95-114. Damas: Direction Générale des Antiquités et de Musées - Syrie.

VENTURI, F.

1996 “Une 'fiasca del pellegrino' da Tell Afis: l'evoluzione dei 'Pilgrim Flasks' cananaici nel passaggio tra bronzo tardo e ferro I," Vicino Oriente 10: 147-161.

2007 La Siria nell'età delle trasformazioni (13-10 sec. a.C.): Nuovi contributi dallo scavo di Tell Afis. Bologna: CLUEB.

2014 "The Late Bronze Age II pottery production from Tell Afis," in Recent Trends in the Study of Late Bronze Age Ceramics in Syro-Mesopotamia and Neighbouring Regions, edited by A. Hausleiter and M. Luciani, pp. 133-156. Rahden: Marie Leidorf. 
WIJNGAARDEN, G. J. VAN

2002 Use and Appreciation of Mycenaean Pottery in the Levant, Cyprus and Italy (16001200 BC). Amsterdam: Amsterdam University Press.

WoOlLeY, C. L.

1955 Alalakh: An Account of the Excavations at Tell Atchana in the Hatay, 1937-1949. Oxford: Society of Antiquaries of London.

WRIGHT, J. C.

2004a "Mycenaean drinking services and standards of etiquette," in Food, Cuisine and Society in Prehistoric Greece, edited by P. Halstead and J. C. Barrett, pp. 90-104. Oxford: Oxbow.

WRIGHT, J. C., ed.

2004b The Mycenaean Feast. Princeton: American School of Classical Studies at Athens.

YASUR-LANDAU, A.

2005 "Old wine in new vessels: Intercultural contact, innovation and Aegean, Canaanite and Philistine foodways," Tel Aviv 32: 168-191.

2010 The Philistines and Aegean Migration at the End of the Late Bronze Age. Cambridge: Cambridge University Press.

YENER, K. A.

2005 "Introduction, Alalakh spatial organization: Augmenting the architectural layout of Levels VII-0," in The Amuq Valley Regional Projects, Volume 1: Surveys in the Plain of Antioch and Orontes Delta, Turkey, 1995-2002, edited by K. A. Yener, pp. 99-144. Chicago: Oriental Institute.

2013 "New excavations at Alalakh: The 14th-12th centuries BC," in Across the Border: Late Bronze-Iron Age Relations between Syria and Anatolia, Proceedings of a Symposium Held at the Research Center of Anatolian Studies, Koç University, Istanbul, May 31-June 1, 2010 (Ancient Near Eastern Studies 42), edited by K. A. Yener, pp. 11-35. Leuven: Peeters.

Yener, K. A. and YazicioĞLu, G. B.

2010 "Excavation results," in Tell Atchana, Ancient Alalakh Volume 1: The 2003-2004 Excavations Seasons, edited by K. A. Yener, pp. 11-50. Istanbul: Koç University Press.

YENER, K. A. and AKAR, M.

2013 "Excavations at Tell Atchana, ancient Alalakh 2012," ANMED, News of Archaeology from Anatolia's Mediterranean Areas 11: 1-9.

Yener, K. A., Peker, H. and Dinçol, B.

2014 "Prince Tuthaliya and Princess Ašnuhepa," NABU: Nouvelles Assyriologiques Breves et Utilitaire 4: 136-138.

Yon, M., Karageorghis, V., Hirschfeld, N. and Caubet, A., eds.

2000 Ras Shamra-Ougarit XIII: Céramiques mycéniennes. Nicosia: Leventis.

Zarnkow, M., Spieleder, E., Back, W., SACher, B., OtTo, A. and Einwag, B

2006 "Interdisziplinäre Untersuchungen zum altorientalischen Bierbrauen in der Siedlung von Tall Bazi/Nordsyrien vor rund 3200 Jahren,” Technikgeschichte 73: 3-25.

ZetTler, R. L. and Miller, N. F.

1996 "Searching for wine in the archaeological record of ancient Mesopotamia of the third and second millennia B.C.," in The Origins and Ancient History of Wine, edited by P. E. McGovern, S. J. Fleming and S. H. Katz, pp. 123-132. Amsterdam: Routledge.

Marina PUCCI 